\title{
Peak Ground Acceleration on Bedrock using Probability Seismic Hazard Analysis Methods in Bandung City
}

\author{
Anggun Mayang Sari ${ }^{1}$, Afnindar Fakhrurrozi ${ }^{2}$, and Arifan Jaya Syahbana ${ }^{3}$ \\ \{anggunmayangsari@lipi.go.id ${ }^{1}$ \} \\ Research Center for Geotechnology, LIPI, Jl. Sangkuriang, Bandung, 40135, Indonesia ${ }^{1,2,3}$
}

\begin{abstract}
As one of the largest cities in Indonesia, Bandung city consists of dense populations that geologically surrounded by earthquake hazards. Therefore, a study on Peak Ground Acceleration (PGA) of the bedrock to analyze seismic hazard is a necessity. This study used the latest updated seismic sources data to model seismic ground motion to a particular location. Furthermore, the Probability Seismic Hazard Analysis (PSHA) methods were applied using EZ-FRisk and OpenQuake software. As a result, PGA bedrock using EZ-FRisk software ranged between 0,48-0,62g, while OpenQuake showed 0,539$565 \mathrm{~g}$. These results validated using Indonesian Hazard Map 2017 using PGA on 2475 years return period, represented similar values about $0.50-0.60 \mathrm{~g}$. In order to provide spatial information, these results visualized using Geographic Information System (GIS) application. Furthermore, this study expected to give contributions to scientific information for development planning, especially for designing earthquake-resistant buildings.
\end{abstract}

Keywords: PGA Bedrock, PSHA, EZ-Frisk, OpenQuake, GIS

\section{Introduction}

Earthquake hazard is one of the potential devastating disasters that is concerned by the Indonesian government nowadays. It can be seen from one of the Indonesian national priorities, as outlined in the Government Work Plan for 2019, which is a priority for disaster prevention programs [1]. The plan for this program focuses on strengthening disaster management capacity. Enhancing disaster management capacity could be done by carrying out disaster risk reduction using a mapping technique. This technique can be applied to the area that has the potential for earthquake disaster.

Bandung is one of the urban cities surrounded by seismic hazard. According to Development Planning Agency at Sub-National Level (BAPPEDA) of West Java Province Metropolitan Development Management (WJP-MDM) data in 2013, the population growth in Bandung Raya region will increase significantly in 2025. This area is categorized as an urban area towards Metropolitan [2]. On the one hand, the development of this area is followed by the increase of active fault movement in the surrounding Bandung basin. As can be seen in Figure 1, based on the National Earthquake Study Center Data 2017, Bandung region surrounded by several faults; namely Cimandiri, Lembang, Nyalindung-Cibeber, Rajamandala and Subang faults [3]. The Lembang active fault has a movement of around 1.95-3.45 mm/year, with an earthquake potential around Mw 6.5-7.0 in 170-670 years per cycle [4]. Thus, the preparedness 
efforts against disasters are required. One of them is disaster-prone areas mapping and reviewing the existing buildings and other structural objects.

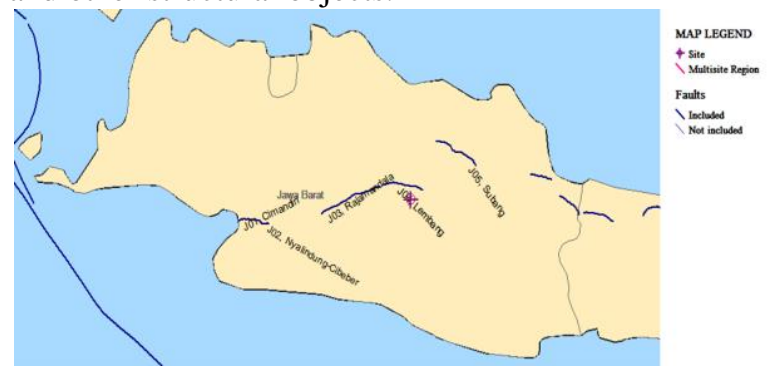

Fig. 1. Several faults influenced seismicity in the Bandung area.

The research location is in the densely populated of the Greater Bandung (Bandung Raya) region. The analysis was carried out at nine CPT / CPTu location points scattered in West Bandung Regency, Bandung Regency, and Bandung City as shown in Figure 2. The measurement points situated in Cibereum, Cikapundung, and Kosambi geological formation. The dissimilar geological condition may have a different value of peak ground acceleration on the bedrock [5-7].

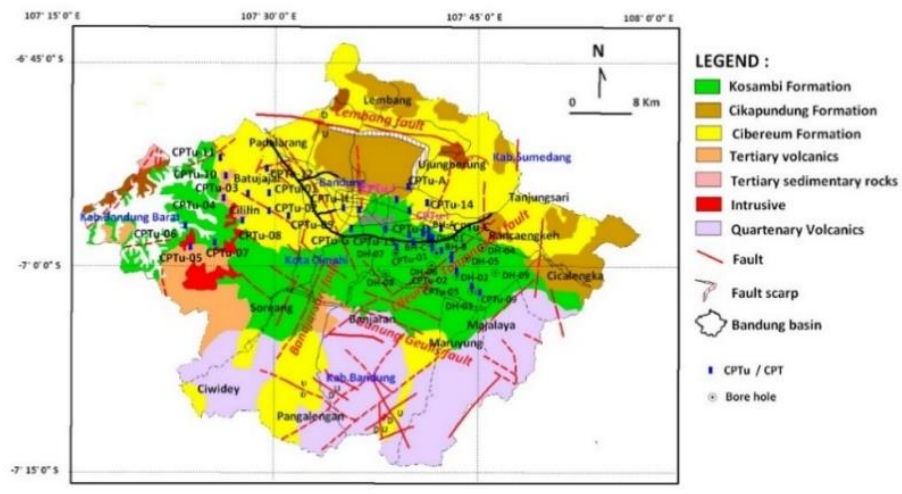

Fig. 2. Peak ground acceleration analysis on $9 \mathrm{CPTu}$ location test.

\section{Seismic Hazard Analysis}

PSHA approach was used in this study to analyze seismic hazard. There were two kinds of applications that used to compute PSHA; namely EZ-Frisk and OpenQuake. EZ Frisk can be used to analyze seismic hazard, perform spectral matching modeling and site response. The seismic source database is required as a primary input to model seismic hazard. In this research, seismic source databases are obtained from National Centre for Earthquake Studies (PUSGEN) (2017) as shown in Table 1 and Table 2. The seismic source can be divided into two; earthquake source thrust and crustal earthquake source. The seismic source databases were calculated within radius 500 meters from the location point of an earthquake source. Then, seismic hazard analysis was carried out using a probability approach, magnitude probabilistic approach, distance, and recurring earthquake events or better known as PSHA. 
Afterward, the uniform hazard spectrum (UHS) curve at the location of all earthquake sources that affected was quantified. The next step is to analyze the disaggregation by calculating the dominant earthquake to get the response spectra of a particular location. Spectral matching modeling between UHS curves and the response curve of the spectra is obtained. Hence, the latest scalable spectral curve is acquired to model historical time against earthquake waves that match with the spectral response. The spectral response is a synthetic ground motion that is obtained in the field. The maximum acceleration value is obtained from the synthetic ground motion. These values are PGA values on the bedrock.

Table 1. Seismic source database for megathrust.

\begin{tabular}{ccccccc}
\hline Structure & Segment & $\begin{array}{c}\mathrm{L} \\
(\mathrm{km})\end{array}$ & $\mathrm{W}$ & $\mathrm{M}$ & $\mathrm{b}$-val & a-val \\
\hline $\begin{array}{c}\text { Sumatran } \\
\text { Megathrust }\end{array}$ & Selat Sunda & 290 & 100 & 8.7 & 1.15 & 5.99 \\
$\begin{array}{c}\text { Sunda } \\
\text { Megathrust } \\
\begin{array}{c}\text { Sunda } \\
\text { Megathrust }\end{array}\end{array}$ & $\begin{array}{c}\text { West- } \\
\text { Central Java' }\end{array}$ & 700 & 150 & 8.7 & 1.08 & 5.55 \\
\hline
\end{tabular}

This study was conducted by collecting earthquake mainshock data in Indonesia from 1900 to 2016. Consider the completeness time of each magnitude, this data was collected using Geophysical Earth Modelling software (GEM). Thus, the outputs can be compared with the Indonesian Earthquake Map 2017 analysis results. The source of the earthquake can be divided into three; namely fault, subduction including inter and intraplate and the background. The faultbased earthquake source data can be seen in Table 3.

Table 2. Seismic source database for shallow crustal.

\begin{tabular}{cccccc}
\hline Segment & Type & Dip & $\begin{array}{c}\text { L } \\
(\mathrm{km})\end{array}$ & $\begin{array}{c}\text { W } \\
(\mathrm{km})\end{array}$ & M Max \\
\hline Kumering-North & SS & $\sim 90$ & 111 & 20 & 7.5 \\
Kumering-South & SS & $\sim 90$ & 60 & 20 & 7.1 \\
Semangko Barat-A & SS & $\sim 90$ & 90 & 20 & 7.4 \\
Semangko Barat-B & SS & $\sim 90$ & 80 & 20 & 7.3 \\
Semangko Timur-A & SS & $\sim 90$ & 12 & 20 & 6.5 \\
Semangko Timur-B & SS & $\sim 90$ & 35 & 20 & 6.9 \\
Semangko Graben & Normal & 60 & 50 & 20 & 6.5 \\
Ujung Kulon A & SS & $\sim 90$ & 80 & 20 & 7.3 \\
Ujung Kulon B & SS & $\sim 90$ & 150 & 20 & 7.6 \\
Cimandiri & R & E-W & 23 & 23 & 6.7 \\
Nyalindung-Cibeber & R & & 30 & 15 & 6.5 \\
Rajamandala & SS & & 45 & 22.5 & 6.6
\end{tabular}




\begin{tabular}{cccccc}
\hline Segment & Type & Dip & $\begin{array}{c}\text { L } \\
(\mathrm{km})\end{array}$ & $\begin{array}{c}\text { W } \\
(\mathrm{km})\end{array}$ & M Max \\
\hline Lembang & SS & E-W & 29.5 & 29.5 & 6.8 \\
Subang & $\mathrm{R}$ & NW & 33 & 16.5 & 6.6 \\
Cirebon-1 & $\mathrm{R}$ & NW & 15 & 7.5 & 6.5 \\
Cirebon--2 & $\mathrm{R}$ & NW & 18 & 9 & 6.5 \\
Karang Malang & $\mathrm{R}$ & EW & 22 & 22 & 6.7 \\
Brebes & $\mathrm{R}$ & & 22 & 11 & 6.5 \\
Tegal & $\mathrm{R}$ & ENE & 15 & 15 & 6.5 \\
Pekalongan & $\mathrm{R}$ & NE & 16 & 16 & 6.6 \\
Weleri & $\mathrm{R}$ & & 17 & 17 & 6.6 \\
Semarang & $\mathrm{R}$ & EW & 34 & 17 & 6.6 \\
Rawapening & $\mathrm{R}$ & $\mathrm{NW}$ & 18 & 9 & 6.5 \\
Demak & $\mathrm{R}$ & EW & 31 & 15.5 & 6.6 \\
Purwodadi & $\mathrm{R}$ & EW & 38 & 19 & 6.7 \\
Cepu & $\mathrm{R}$ & ESE & 100 & 50 & 7.1 \\
\hline
\end{tabular}

The Ground Motion Prediction Equations (GMPE) attenuation was used is using GMPE that developed by PUSGEN. The logic tree of GMPE can be described as follows: (1) to analyse shallow earthquake sources (fault and background) are BooreEtAl 2014, CampbellBozorgnia2014, ChiouYoungs2014, (2) interslab earthquake analysis (shallow subduction) are AbrahamsonEtA12015Sinter, AtkinsonBoore2003Sinter, ZhaoEtAl2006Asc and (3) intraslab earthquake source analysis (deep subduction) is with AtkinsonBoore2003SSlab, YoungsEtAl1997SSlab, AbrahamsonEtA12015SSlab with each weight is $0.33 ; 0.33$ and 0.34 .

Table 3. Fault-based earthquake sources.

\begin{tabular}{|c|c|c|c|c|c|c|c|c|c|}
\hline \multirow{2}{*}{ ID } & \multicolumn{2}{|c|}{ Structure Name } & \multirow{2}{*}{$\begin{array}{l}\text { Slip- } \\
\text { Rate } \\
\mathrm{mm} / \mathrm{yr}\end{array}$} & \multirow{2}{*}{$\begin{array}{c}\text { Sense } \\
\text { Mechanism }\end{array}$} & \multirow{2}{*}{$\begin{array}{l}\text { Dip } \\
(\mathrm{km})\end{array}$} & \multirow{2}{*}{$\begin{array}{c}\text { Top } \\
(\mathrm{km})\end{array}$} & \multirow{2}{*}{$\begin{array}{c}\text { Bottom } \\
(\mathrm{km})\end{array}$} & \multirow{2}{*}{$\begin{array}{c}\mathrm{L} \\
(\mathrm{km})\end{array}$} & \multirow{2}{*}{$\begin{array}{l}\operatorname{Mmax} \\
(\mathrm{Mw})\end{array}$} \\
\hline & Main & Segment & & & & & & & \\
\hline 1 & $\begin{array}{c}\text { Cimandiri } \\
\text { Fault }\end{array}$ & Cimandiri & 0.55 & Reverse-slip & $45 \mathrm{~S}$ & 3 & 18 & 23 & 6.7 \\
\hline 2 & $\begin{array}{c}\text { Cimandiri } \\
\text { Fault }\end{array}$ & $\begin{array}{l}\text { Nyalindung- } \\
\text { Ciheber }\end{array}$ & 0.4 & Reverse-slip & $45 \mathrm{~S}$ & 3 & 18 & 30 & 6.5 \\
\hline 3 & $\begin{array}{c}\text { Cimandiri } \\
\text { Fault }\end{array}$ & Rajamandala & 0.1 & Strike-slip & 90 & 3 & 18 & 45 & 6.6 \\
\hline 4 & $\begin{array}{l}\text { Lembang } \\
\text { Fault } \\
\text { Baribis- }\end{array}$ & Lembang & 2.0 & Strike-slip & 90 & 3 & 18 & 29.5 & 6.8 \\
\hline 5 & $\begin{array}{l}\text { Kendeng } \\
\text { Fold-Thrust } \\
\text { Zone }\end{array}$ & Subang & 1 & Reverse-slip & $45 \mathrm{~S}$ & 3 & 18 & 33 & 6.5 \\
\hline 6 & $\begin{array}{c}\text { Baribis- } \\
\text { Kendeng } \\
\text { Fold-Thrust } \\
\text { Zone }\end{array}$ & Cirebon-1 & 0.1 & Reverse-slip & $45 \mathrm{~S}$ & 3 & 18 & 15 & 6.5 \\
\hline
\end{tabular}




\begin{tabular}{|c|c|c|c|c|c|c|c|c|c|}
\hline \multirow{2}{*}{ ID } & \multicolumn{2}{|c|}{ Structure Name } & \multirow{2}{*}{$\begin{array}{l}\text { Slip- } \\
\text { Rate } \\
\mathrm{mm} / \mathrm{yr}\end{array}$} & \multirow{2}{*}{$\begin{array}{c}\text { Sense } \\
\text { Mechanism }\end{array}$} & \multirow{2}{*}{$\begin{array}{l}\text { Dip } \\
(\mathrm{km})\end{array}$} & \multirow{2}{*}{$\begin{array}{l}\text { Top } \\
(\mathrm{km})\end{array}$} & \multirow{2}{*}{$\begin{array}{c}\text { Bottom } \\
(\mathrm{km})\end{array}$} & \multirow{2}{*}{$\begin{array}{c}\mathrm{L} \\
(\mathrm{km})\end{array}$} & \multirow{2}{*}{$\begin{array}{c}\mathrm{Mmax} \\
(\mathrm{Mw})\end{array}$} \\
\hline & Main & Segment & & & & & & & \\
\hline 7 & $\begin{array}{l}\text { Baribis- } \\
\text { Kendeng } \\
\text { Fold-Thrust } \\
\text { Zone }\end{array}$ & Cirebon-2 & 0.1 & Reverse-slip & $45 \mathrm{~S}$ & 3 & 18 & IS & 6.5 \\
\hline 8 & $\begin{array}{c}\text { Baribis- } \\
\text { Kendeng } \\
\text { Fold-Thrust } \\
\text { Zone }\end{array}$ & $\begin{array}{l}\text { Karang } \\
\text { Malang }\end{array}$ & 0.1 & Reverse-slip & $45 \mathrm{~S}$ & 3 & 18 & 22 & 6.5 \\
\hline 9 & $\begin{array}{l}\text { Baribis- } \\
\text { Kendeng } \\
\text { Fold-Thrust } \\
\text { Zone }\end{array}$ & Brebes & 0.1 & Reverse-slip & $45 \mathrm{~S}$ & 3 & 18 & 22 & 6.5 \\
\hline 10 & $\begin{array}{l}\text { Baribis- } \\
\text { Kendeng } \\
\text { Fold-Thrust } \\
\text { Zone }\end{array}$ & Tegal & 0.1 & Reverse-slip & $45 \mathrm{~S}$ & 3 & 18 & 15 & 6.5 \\
\hline 11 & $\begin{array}{l}\text { Baribis- } \\
\text { Kendeng } \\
\text { Fold-Thrust } \\
\text { Zone }\end{array}$ & Pekalongan & 0.1 & Reverse-slip & $45 \mathrm{~S}$ & 3 & 18 & 16 & 6.5 \\
\hline 12 & $\begin{array}{c}\text { Baribis- } \\
\text { Kendeng } \\
\text { Fold-Thrust } \\
\text { Zone }\end{array}$ & Weleri & 0.1 & Reverse-slip & $45 \mathrm{~S}$ & 3 & 18 & 17 & 6.5 \\
\hline 13 & $\begin{array}{l}\text { Baribis- } \\
\text { Kendeng } \\
\text { Fold-Thrust } \\
\text { Zone }\end{array}$ & Semarang & 0.1 & Reverse-slip & $45 \mathrm{~S}$ & 3 & 18 & 34 & 6.5 \\
\hline 14 & $\begin{array}{l}\text { Baribis- } \\
\text { Kendeng } \\
\text { Fold-Thrust } \\
\text { Zone }\end{array}$ & Rawa-Pening & 0.1 & Reverse-slip & $45 \mathrm{~S}$ & 3 & 18 & 18 & 6.5 \\
\hline 15 & $\begin{array}{l}\text { Baribis- } \\
\text { Kendeng } \\
\text { Fold-Thrust } \\
\text { Zone }\end{array}$ & Demak & 0.1 & Reverse-slip & $45 \mathrm{~S}$ & 3 & 18 & 31 & 6.5 \\
\hline 16 & $\begin{array}{l}\text { Baribis- } \\
\text { Kendeng } \\
\text { Fold-Zone }\end{array}$ & Purwodadi & 0.1 & Reverse-slip & $45 \mathrm{~S}$ & 3 & 18 & 38 & 6.5 \\
\hline 17 & $\begin{array}{l}\text { Baribis- } \\
\text { Kendeng } \\
\text { Fold-Zone }\end{array}$ & Серu & 0.1 & Reverse-slip & $45 \mathrm{~S}$ & 3 & 18 & 100 & 63.0 \\
\hline 18 & $\begin{array}{l}\text { Baribis- } \\
\text { Kendeng } \\
\text { Fold-Thrust } \\
\text { Zone }\end{array}$ & Waru & 0.05 & Reverse-slip & $45 \mathrm{~S}$ & 3 & 18 & 64 & 6.5 \\
\hline 19 & $\begin{array}{l}\text { Baribis- } \\
\text { Kendeng } \\
\text { Fold-Thrust } \\
\text { Zone }\end{array}$ & Surabaya & 0.05 & Reverse-slip & $45 \mathrm{~S}$ & 3 & 18 & 25 & 6.5 \\
\hline 20 & $\begin{array}{l}\text { Baribis- } \\
\text { Kendeng } \\
\text { Fold-Thrust } \\
\text { Zone }\end{array}$ & Blumbang & 0.05 & Reverse-slip & $45 \mathrm{~S}$ & 3 & 18 & 31 & 6.6 \\
\hline 21 & Ciremai & & 0.1 & Strike-slip & 90 & 3 & 18 & 20 & 6.5 \\
\hline
\end{tabular}




\begin{tabular}{|c|c|c|c|c|c|c|c|c|c|}
\hline \multirow{2}{*}{ ID } & \multicolumn{2}{|c|}{ Structure Name } & \multirow{2}{*}{$\begin{array}{l}\text { Slip- } \\
\text { Rate } \\
\mathrm{mm} / \mathrm{yr}\end{array}$} & \multirow{2}{*}{$\begin{array}{c}\text { Sense } \\
\text { Mechanism }\end{array}$} & \multirow{2}{*}{$\begin{array}{l}\text { Dip } \\
(\mathrm{km})\end{array}$} & \multirow{2}{*}{$\begin{array}{l}\text { Top } \\
(\mathrm{km})\end{array}$} & \multirow{2}{*}{$\begin{array}{l}\text { Bottom } \\
(\mathrm{km})\end{array}$} & \multirow{2}{*}{$\begin{array}{c}\mathrm{L} \\
(\mathrm{km})\end{array}$} & \multirow{2}{*}{$\begin{array}{c}\mathrm{Mmax} \\
(\mathrm{Mw})\end{array}$} \\
\hline & Main & Segment & & & & & & & \\
\hline 22 & Ajibarang & & 0.1 & Strike-slip & 90 & 3 & 18 & 20 & 6.5 \\
\hline 23 & Opak & & 0.75 & Strike-slip & $60 \mathrm{E}$ & 3 & 18 & 45 & 6.6 \\
\hline 24 & $\begin{array}{l}\text { Merapi- } \\
\text { Merbabu }\end{array}$ & & 0.1 & Strike-slip & 90 & 3 & IS & 28 & 6.6 \\
\hline 25 & Pati Thrust & & 0.1 & Strike-slip & 90 & 3 & 18 & 69 & 6.5 \\
\hline
\end{tabular}

\section{Result and Discussion}

The results of the PSHA analysis using the Ez-Frisk software, the PGA values obtained ranged from 0.48 - $0.61 \mathrm{~g}$. The distribution of these PGA values can be seen in Figure 3a The maximum PGA value is around Antapani - Arcamanik area. As for the minimum PGA value is in the regolith region. The PSHA analysis results using the OpenQuake software, the PGA values ranged from $0.539-0.565 \mathrm{~g}$. As it can be seen in Figure 3b, the maximum PGA value is located in the area around Antapani - Coblong, Bandung city. As for the minimum PGA value is located in the Bandung regency area, situated around Rancasari. The discrepancy of these results is influenced by the source of the fault and the subduction earthquake used.

In addition, consider the geological factor and soil condition. Bandung regency area is far from the Lembang fault, while the Bandung city area; namely Coblong - Antapani, is close to the Lembang fault. As for the soil condition, Bandung regency has Kosambi formation, which formed from young rock formations. While the surrounding area of Antapani is located in the Cibeureum formation area, which formed from a harder (old) rock layer.
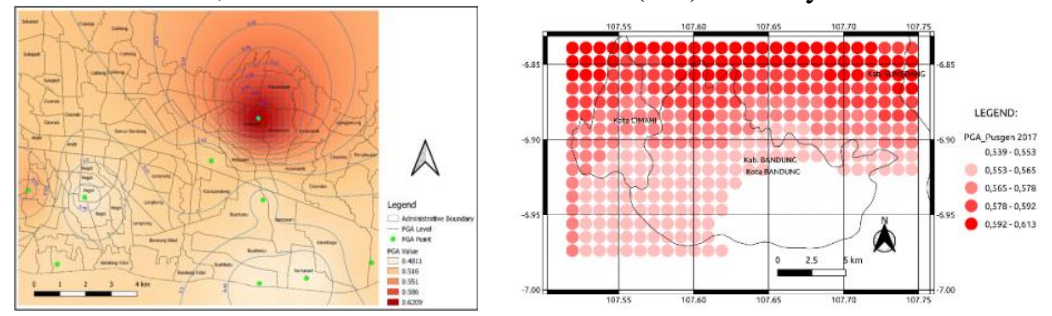

Fig. 3. a) PGA on bedrock using EZ-Frisk oftware, b) PGA on bedrock using OpenQuake software.

\section{Conclusion}

The results of the PSHA analysis using both Ez-Frisk and OpenQuake software are fit the national earthquake map which ranged from 0.50-0.60 g for the 2475-year annual earthquake return period. The high wave propagation occurs on the younger rock layer formation, while the minimum wave propagation value happens on the hard rock layer.

The Ez-Frisk or OpenQuake software can produce valid results, depend on the particular objectives. OpenQuake can estimate the risks that can be generated from a particular earthquake event. In addition, OpenQuake software can be used freely by all users. However, it requires expertise in the python programming language to run this application. Ez-Frisk is more user- 
friendly and still being used widely. On the other hand, it is paid and requires a fairly expensive fee to use.

As for the analysis results, both Ez-frisk and OpenQuake are able to show detailed results related to seismic hazard in a particular area. In the future, these data can be used as a basis for a scientific decision in the infrastructure and residential building constructions.

\section{References}

[1] National Development Planning Agency, Goverment Work Plan (2019)

[2] Regional Development Planning Agency, WJP-MDM Report (2013)

[3] National Earthquake Study Center, Earthquake Source and Hazard Map (2017)

[4] Daryono, M. R., Natawidjaja, D. H., Sapiie, B., \& Cummins, P.: Earthquake geology of the lembang fault, West Java, Indonesia. Tectonophysics, Vol. 751, pp. 180-191 (2019)

[5] Borcherdt, R. D.: Effects of local geology on ground motion near San Francisco Bay. Bulletin of the Seismological Society of America, Vol. 60, No. 1, pp. 29-61 (1970)

[6] Borcherdt, R. D., \& Glassmoyer, G.: On the characteristics of local geology and their influence on ground motions generated by the Loma Prieta earthquake in the San Francisco Bay region, California. Bulletin of the seismological society of America, 82(2), pp. 603-641 (1992)

[7] Nikolaou, S.: Local geology of New York City and its effect on seismic ground motions (2004) 